\title{
Effect of pH on Homogeneous Photodegradation of Eosin Y Dye
}

\author{
Subrata Chandra Roy ${ }^{* 1}$, Abu Jafar Mahmood ${ }^{2}$ \\ ${ }^{1}$ Department of Chemistry, Jagannath University, Dhaka-1100, Bangladesh \\ ${ }^{2}$ Department of Chemistry, University of Dhaka-1000, Bangladesh \\ *Corresponding E-mail: scroy1979@yahoo.com
}

(Received: July 14, 2020; Revised: January 4, 2021; \& Accepted: January 4, 2021)

\begin{abstract}
Eosin Y (EY), an anionic dye, also known as Eosin Yellow or Bromoeosin, or Acid red 27 is an industrial dye. The residual dye, discharged as one of the components of the untreated effluent, into the adjacent surface and causes water pollution. Photodegradation of EY was investigated at $29{ }^{\circ} \mathrm{C}$ in homogeneous aqueous media using $\mathrm{UV}_{\mathrm{A}}$ light $(\approx 400-320 \mathrm{~nm})$ in acetate buffer solution as a function of $\mathrm{pH}(3.08-7.08)$. At higher $\mathrm{pH}$, there was no effect of this light on the dye in the solution. Results show that the initial rate of photocolorization increased with decreasing the $\mathrm{pH}$ of the dye solution.
\end{abstract}

Keywords: photocolorization, pH effect, Acid red 27, UV light, homogeneous media.

\section{Introduction}

In the recent past, Asia contributed $42 \%$ of the total dye user market [1]. The global dyestuff market was estimated to be about 6.6 billion US dollars in 1999 and $\mathrm{EY}$ has been one of the widely used dye. $\mathrm{pH}$ causes changes in its structural configuration in water (Figure 1). Due to its vivid red fluorescence, EY is used in the textile, printing, leather, and cosmetic industries. It is reported that in industries about $15 \%$ of total dye used, is lost during processing with water and the effluent pollutes the natural water system [2]. Several physical methods such as membrane filtration, adsorption on activated charcoal, reverse osmosis, flocculation, chemical method, and bio-treatment are applied to remove dye from wastewater. Scientists are still trying to degrade dyes from wastewater by heterogeneous oxidation using semiconducting photocatalyst [3-10]. Recently, Hossain et al. [11] tried to degrade $\mathrm{EY}$ by homogeneous oxidation using the Fenton process (i.e. in presence of $\mathrm{H}_{2} \mathrm{O}_{2}$ and $\mathrm{Fe}^{2+}$ ). However, homogeneous photo-degradation of $\mathrm{EY}$ dye has not been studied yet. This study reports the influence of only $\mathrm{H}^{+} / \mathrm{OH}^{-}$ion concentrations on the degradation of EY dye in aq. solution, in the presence of $\mathrm{UV}_{\mathrm{A}}$ light alone.

\section{Materials and Methods}

Microcrystalline yellowish Eosin Y (reagent grade) was collected from the local market and used without any further treatment. Other analytical grade (AR) chemicals, such as glacial acetic acid, and sodium acetate, etc., were purchased from E. Merck, Germany. Deionized water was used to prepare all solutions. The spectra were recorded with Shimadzu UV-vis 160 (Japan) spectrophotometer.<smiles>O=C(O[Na])c1ccccc1-c1c2cc(Br)c(=O)c(Br)c-2oc2c(Br)c(O[N+](=O)[O-])c(Br)cc12</smiles>

$\mathrm{Na}_{2} \mathrm{EY}$ (solid)<smiles>O=C([O-])c1ccccc1-c1c2cc(Br)c(=O)c(Br)c-2oc2c(Br)c([O-])c(Br)cc12</smiles>

$\mathrm{EY}^{2-}$ (aq) $\mathrm{pH} \sim 6$
$\operatorname{HEY}^{-}(\mathrm{aq}) \mathrm{pH}=3-5$

Figure 1: Structure of Eosin $Y(E Y)$ at different $p H$ 


\section{Preparation of stock solution of Eosin Y (EY) dye}

A stock solution of $1.00 \times 10^{-2} \mathrm{M}$ of EY was prepared by dissolving $0.692 \mathrm{~g}$ solid dye in water in a $100 \mathrm{~mL}$ volumetric flask. This stock solution was wrapped with aluminum foil and kept in the dark. EY solutions with five different concentrations $1 \times 10^{-5}, 2 \times 10^{-5}$, $3 \times 10^{-5}, 4 \times 10^{-5}$, and $5 \times 10^{-5} \mathrm{M}$ were prepared from the stock solution and their absorbance was measured at $515 \mathrm{~nm}$ ( $\lambda_{\max }$ of EY). The plot of absorbance vs. the respective concentration showed the compliance of the system with the Beer-Lambert law. $4.96 \times 10^{4}$ $\mathrm{L} \cdot \mathrm{mol}^{-1} \cdot \mathrm{cm}^{-1}$ is the molar absorption coefficient of EY (at $\mathrm{pH}=6.2$ ).

\section{Determination of photodegradation}

Photodegradation of EY was performed in the UV lamp house which was a rectangular wooden box $(25 \times 20 \times 25 \mathrm{~cm})$ with its internal surface wrapped with aluminum foil (Figure 2). The circular shape of $U_{A}$ lamp (20 cm length, 20W), was attached at the inner top of the chamber, as the light source. $50 \mathrm{~mL}$ beaker (dia. $4.0 \mathrm{~cm}$ ) made of borosilicate glass was used as the reactor. A small bar magnet agitated the solution.

In a typical photolysis experiment after every five minutes, the beaker was taken out from the lamphouse and the absorbance was recorded. The removal of the solution for spectroscopic analysis does not affect the photolytic process very much. Because before and after the UV irradiation step the weight of the beaker with EY solution was maintained constant by the addition of deionized water to minimize the error due to vaporization of water from the beaker during photolysis reaction. Furthermore, the photolysis process is carried out in the darkroom.

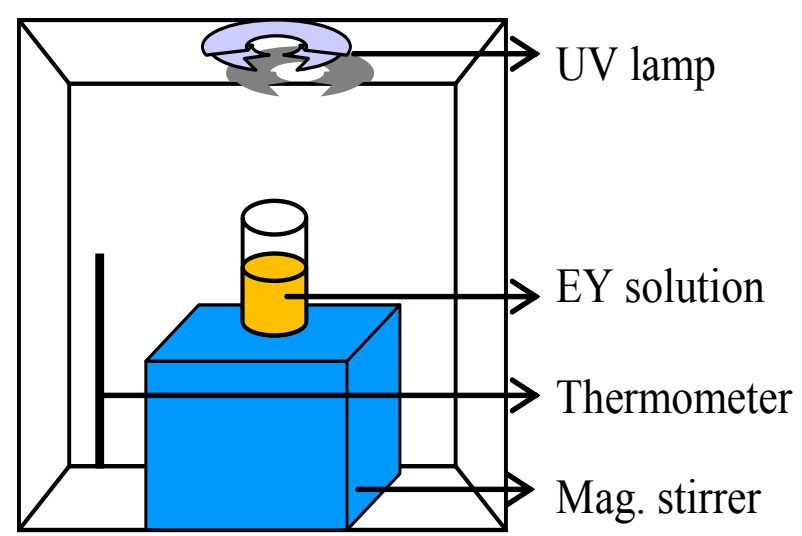

Figure 2: Schematic diagram of UV lamp house for the photodegradation of $E Y$ dye

\section{Determination of initial rates}

Habib et al. reported in 2004, and 2013 [12,6] that pseudo-first-order kinetics give rather perfect rate data than normally accepted second-order kinetics. The concentration of EY solution was measured at different time intervals e.g. 5,10,15,20 min. etc. and the pseudo-first-order rate constant $\left(\mathrm{k}, \mathrm{min}^{-1}\right)$ was obtained from the slope of LnA vs. time (min.) plot. The initial rates were calculated from the observed pseudo-first-order rate constants, according to the following Eq. (1)

$$
R_{i}=\frac{d[E Y]}{d t}=k[E Y]=k \frac{A_{0}}{\varepsilon l} \quad e q .1
$$

Where, $\varepsilon=$ molar absorption coefficient of $\mathrm{EY}$ $\left(\mathrm{L} \cdot \mathrm{mol}^{-1} \cdot \mathrm{cm}^{-1}, \mathrm{k}^{\prime}=\right.$ pseudo-first-order rate constant $\left(\mathrm{min}^{-1}\right)$ obtained from the plot of slope of LnA vs. time $(\mathrm{min}), R_{\mathrm{i}}=$ initial rate $\left(\mathrm{mol} \cdot \mathrm{L}^{-1} \cdot \mathrm{min}^{-1}\right), l=$ cell path length $(1 \mathrm{~cm}), \mathrm{A}_{\mathrm{o}}=$ absorbance at $\mathrm{t}=0(\mathrm{~min})$.

\section{Determination of \% of decolorization}

The percentage of decolorization was calculated as

$$
\left[\left(\mathrm{X}_{0}-\mathrm{X}_{\mathrm{t}}\right) / \mathrm{X}_{0}\right] \times 100
$$

where, $X_{t}$ is the absorbance at the time ' $t$ ' and $X_{0}$ is the absorbance at the time ' $\mathrm{t}$ ' $=0(\mathrm{~min})$.

\section{Results and Discussion}

The spectrum of EY in aqueous solution (Figure 3) shows four absorption peaks at 515, 340, 301, and 253 $\mathrm{nm}$ corresponding to the chromospheres containing a polycyclic aromatic ring, carboxylic group, carbonyl group, and benzene ring, respectively.

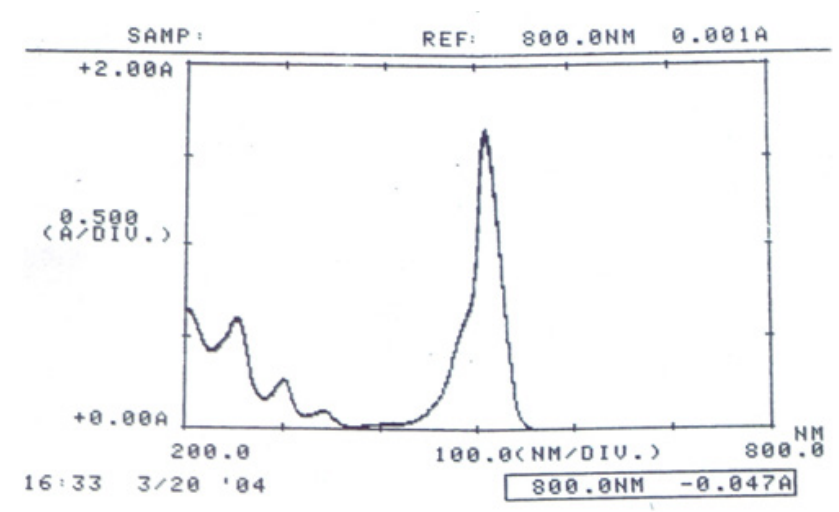

Figure 3: The spectrum of Eosin $Y$ (aq.), $p H=6.2$

$$
[E Y]=3.0 \times 10^{-5} \mathrm{M}
$$

EY solutions of $3.00 \times 10^{-5} \mathrm{M}$ with six different $\mathrm{pH}$ (from 2 to 9$)$ were made by taking $15 \mathrm{~mL}$ of $\left(1.00 \times 10^{-}\right.$ $\left.{ }^{4} \mathrm{M}\right)$ solution in a $50 \mathrm{~mL}$ volumetric flask. The $\mathrm{pH}$ of the solutions was controlled by using the acetate 


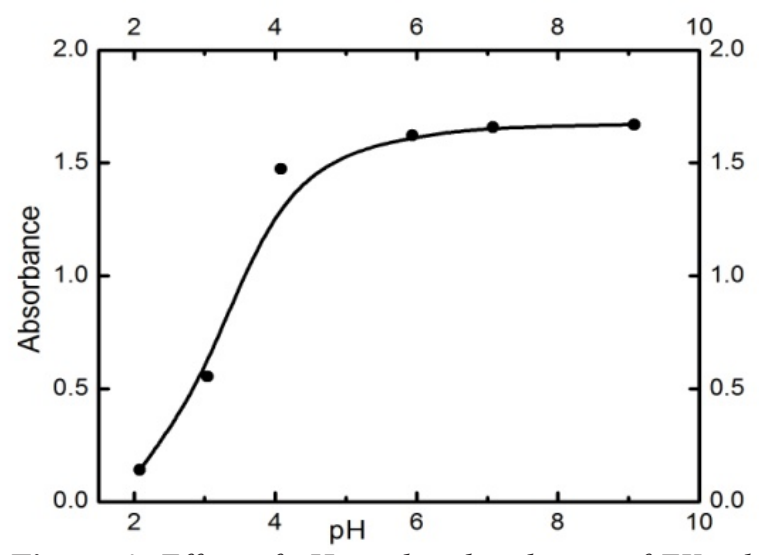

Figure 4: Effect of $p H$ on the absorbance of EY solution $\left(3.00 \times 10^{-5} \mathrm{M}\right)$

buffer. The plot of absorbance vs. $\mathrm{pH}$ of the $3.00 \times 10^{-5}$ $\mathrm{M}$ solution shows (Figure 4) that the absorbance of EY solution at neutral $\mathrm{pH}$ is 1.66 . With increasing the $\mathrm{pH}$ (up to 9) the absorbance remains almost constant however, the absorbance decreases with lowering the $\mathrm{pH}$ of the solution.

\section{pH Effect on the absorbance of Eosin Y solution}

At low $\mathrm{pH}$, the EY solution gets protonated and
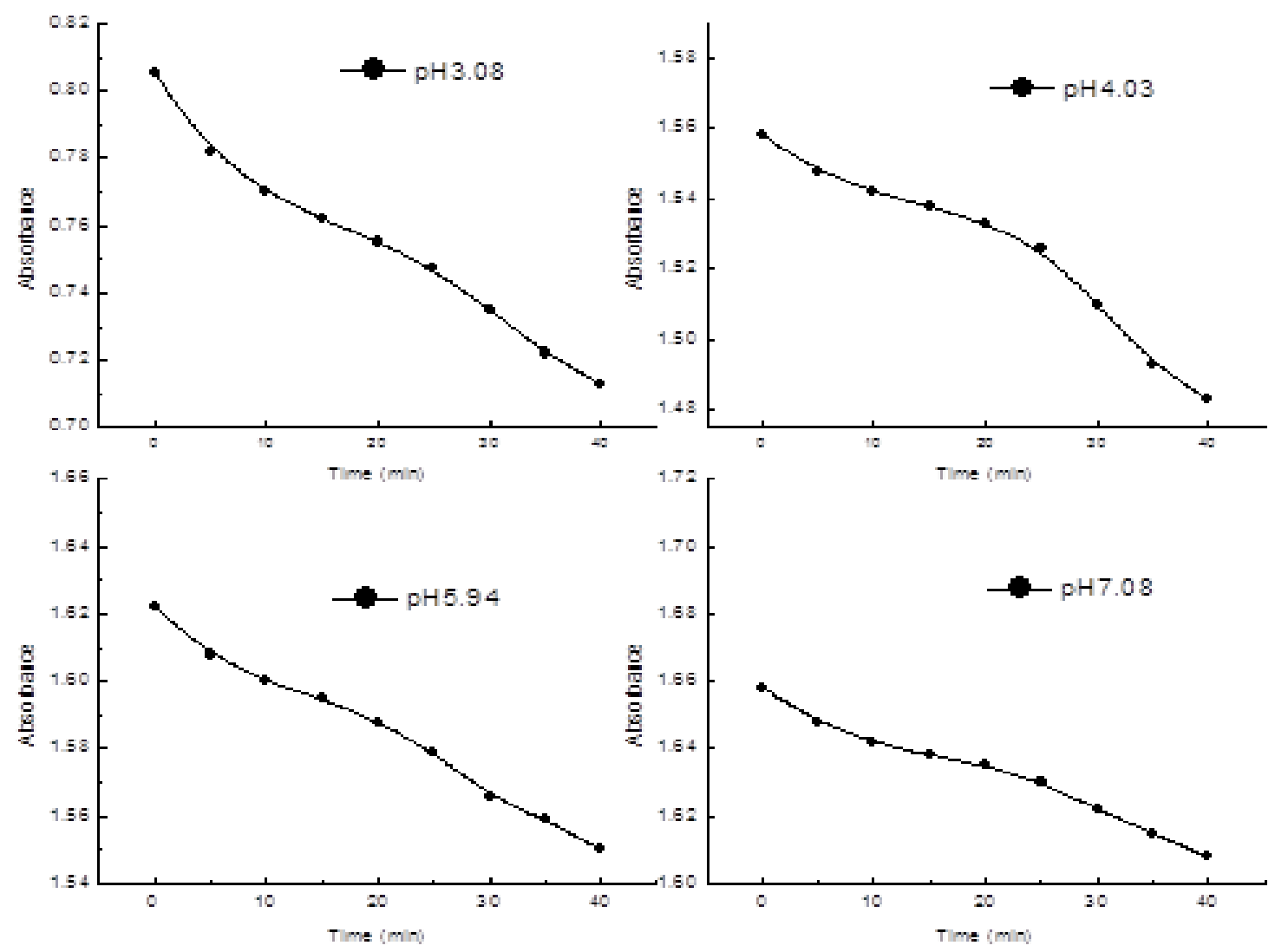

Figure 6: The disappearance of the color of $E Y$ solution with illumination time of $U V_{A}$ light at different $p H$ 
concentration varies with $\mathrm{pH}$ therefore it is necessary to check the validity of the Beer-Lambert law and find out the molar absorption coefficient at different $\mathrm{pH}$. For that reason at a particular concentration of EY, the absorbance was measured at four different pH. Similarly, the molar absorption coefficient of four different EY solutions was calculated from the corresponding absorbance vs. concentration plots. As the absorbance decreases with decreasing the $\mathrm{pH}$ of EY solution in the same way the molar absorption coefficient decreases with decreasing the $\mathrm{pH}$ of $\mathrm{EY}$ solution (Figure 5).

Although the photodecolorization and photodegradation of organic dyes are not the same things they are related. It is considered that the photodecolorization of EY solution is proportional to its photodegradation. [11]. With UV light irradiation, at a particular concentration of EY the initial rate of photo-degradation increases with decreasing the $\mathrm{pH}$ (see Fig. 6 and Table 1). After 40 minutes of irradiation of $\mathrm{UV}_{\mathrm{A}}$ light, the photodegradation of EY solution at $\mathrm{pH} \approx 3$ was only $11 \%$ (Figure 6 and Table 1 ). The illumination of dye solution by $\mathrm{UV}_{\mathrm{A}}$ light initiates the generation of kinetically important oxidizing radicals in the low $\mathrm{pH}$ range. These radicals ultimately lead to the degradation of EY to $\mathrm{CO}_{2}, \mathrm{H}_{2} \mathrm{O}, \mathrm{Br}^{-}$(aq.), and $\mathrm{Na}^{+}$(aq.). In the $\mathrm{pH}$ range of the dye solution above 7, $\mathrm{UV}_{\mathrm{A}}$ light causes hardly any degradation (Table 1). The initial rate of decolorization of $E Y$ increases with lowering the $\mathrm{pH}$. This was also observed in Fenton's process [13]. The decrease of the initial rate of decolorization or the decrease of the percentage of decolorization of Eosin Y under UV light irradiation with $\mathrm{pH}$ suggests that the electron transfer process, which causes the degradation, becomes increasingly difficult as the initial $\mathrm{pH}$ of the solution increases.

Table 1: Influences of $\mathrm{pH}$ on initial rate and percentage of decolorization of $E Y$ solution with $U V_{A}$ light

\begin{tabular}{ccc}
\hline $\begin{array}{c}\text { The } \mathbf{p H} \\
\text { of EY } \\
\text { solution }\end{array}$ & $\begin{array}{c}\text { Initial rate of } \\
\text { decolorization } \\
\left(\text { molL }^{-1} \mathbf{m i n}^{-1}\right)\end{array}$ & $\begin{array}{c}\text { Percent of } \\
\text { decolorization } \\
(\%)\end{array}$ \\
\hline 3.08 & $1.76 \times 10^{-7}$ & 11.43 \\
4.03 & $1.00 \times 10^{-7}$ & 5.29 \\
5.94 & $0.60 \times 10^{-7}$ & 4.32 \\
7.08 & $0.50 \times 10^{-7}$ & 3.01 \\
\hline
\end{tabular}

\section{Conclusions}

Photodegradation of EY dye in homogeneous media certainly depends on the $\mathrm{pH}$ of the solution. At low $\mathrm{pH}$ (3.08) without the presence of any photocatalyst, the percentage of degradation of EY is about 12. Though this quantity is small but not negligible. It decreases with increasing the $\mathrm{pH}$ of the solution. At neutral media $(\mathrm{pH}=7.08)$ the photodegradation is almost negligible. There is no effect on the absorbance of EY solution at the basic $\mathrm{pH}$ range. The initial rate of decolorization also increases with increasing the $\mathrm{pH}$ of the solution. This is because the electron transfers process, causing the degradation, becomes increasingly difficult as the initial $\mathrm{pH}$ of the solution is decreased.

\section{Acknowledgment}

The authors are grateful to the Department of Chemistry, University of Dhaka, Dhaka-1000, Bangladesh for the logistic support during this research work.

\section{References}

1. D. Wesenberg, I. Kyriakides, S. N. Agathos, White-rot fungi and their enzymes for the treatment of industrial dye effluents, Biotecnology Advances, 2003, 22, 161-187. (DOI: $\quad$ 10.1016/j.biotechadv.2003.08.011).

2. A. A. Vaidya, K. V. Datye, Environ-mental pollution during chemical proce sssing of synthetic fibres, Colourage, 1982, 14, 3-10.

3. S. O, Oppong W. W. Anku, F. Opoku, S. K. Shukla, P. P. Govender, Photodegradation of Eosin yellow dye in water under simulated solar light irradiation using La-doped $\mathrm{ZnO}$ nanostructure decorated on graphene oxide as an advanced photocatalyst, Chemistry Select, 2018, 3, 1180-1188. (DOI: 10.1002/slct.201702470).

4. E. Alzahrani, Photodegradation of Eosin Y using silver-dopedmagneticnanoparticles, International Journal of Analytical Chemistry, 2015, Article ID 797606, 11 pages. (DOI: 10.1155/2015/797606).

5. T. S. Anirudhan, S. R. Rajeena, Photocatalytic degradation of eosin yellow using poly(pyrroleco-aniline)-coated $\quad \mathrm{TiO}_{2}$ nanocellulose composite under solar light irradiation, Journal of Materials, 2015, Article ID 636409. (DOI: 10.1155/2015/636409).

6. A. Habib, M. Muslim, T. Shahadat, N. Islam, I. M. I. Ismail, T. S. A. Islam, A. J. Mahmood, Photocatalytic decolorization of crystal violet in aqueous nano- $\mathrm{ZnO}$ suspension under visible light irradiation, Journal of Nanostructure in Chemistry, 2013, 3, 70-79. (DOI: 10.1186/2193-8865-3-70).

7. D. S. Meshesha, S. R. Tirukkovalluri, M. R. Chandra, S. Bojja, Visible light assisted degradation of Eosin yellow using, 
aeteroatom functionalized $\mathrm{TiO}_{2}$ nanomaterial, International Journal of Engineering Research and Application, 2016, 6, 110-121.

8. L. B. Reutergardh, M. Iangphasuk, Photocatalytic decolourization of reactive azo dye: A comparison between $\mathrm{TiO}_{2}$ and us photocatalysis, Chemo. Sphere, 1997, 35, 585596. (DOI: 10.1016/S0045-6535(97)00122-7).

9. M. Saquib, M. Muneer, J. Environ, Photocatalytic degradation of two selected textile dye derivatives, eosine yellowish and p-rosaniline, in aqueous suspensions of titanium dioxide, Journal of Envionmental Science and Health Part A, 2003, 38(11), 2581-2598. (DOI: 10.1081/ESE-120024448).

10. F. Zhang, J. Zhao, T. Shen, H. Hidaka, E. Pelizzetti, N. Serpone, $\mathrm{TiO}_{2}$-assisted photodegradation of dye pollutants II. Adsorption and degradation kinetics of eosin in $\mathrm{TiO}_{2}$ dispersions under visible light irradiation, Applied Catalysis B: Environmental, 1998, 15, 147156. (DOI: 10.1016/S0926-3373(97)00043-X).
11. A. Hossain, A. B. M. S. Rayhan, Md. J Raihan, A. Nargis, I. M. I. Ismail, A. Habib, A. J. Mahmood, Kinetics of degradation of Eosin $\mathrm{Y}$ by one of the advanced oxidation processes (AOPs)-Fenton's process, American Journal of Analytical Chemistry, 2016, 7, 863-879. (DOI: 10.4236/ajac.2016.712074).

12. A. Habib, M. Tabata, Y. Wu, Kinetics and mechanism of Gold(III) incorporation into Tetrakis2(1-Methyl pyridium-4-yl) Porphyrin in aqueous solution, Journal of Porphyrins and Phthalocyanines, 2004, 8, 12691275. (DOI: 10.4236/ajac.2016.712074).

13. N. Daneshvarb, M. Rabbania, N. Modirshahla, and M. A. Behnajady, Photo-oxidative degradation of acid red 27 in a Tubular continuousflow photoreactor: Influence of operational parameters and mineralization products, Journal of Hazardous Materials, 2005, B118, 155160. (DOI :10.1016/j.jhazmat.2004.10.007). 